\title{
Faktor-Faktor yang Mempengaruhi Status Gizi Pasien Hemodialisis di Rumah Sakit Stella Maris Makassar
}

\author{
Yunita Carolina Satti ${ }^{1}$, Sry Reski Mistika ${ }^{2}$, Laorensi Imelda ${ }^{3}$ \\ ${ }^{1,2,3}$ Program Studi Ilmu Keperawatan, Sekolah Tinggi Ilmu Kesehatan Stella Maris Makassar
}

\begin{tabular}{l}
\hline Info Artikel \\
\hline Riwayat Artikel: \\
Received : 31 Mei 2021 \\
Revised : 20 Juni 2021 \\
Accepted : 25 Juni 2021 \\
\hline
\end{tabular}

Kata Kunci:

Ginjal Kronik

Hemodialisis

Status Gizi

\begin{abstract}
ABSTRAK
Malnutrisi masih merupakan masalah utama pada pasien yang menjalani terapi hemodialisis sehingga dapat menyebabkan status gizi buruk yang merupakan predictor terjadinya kematian pada pasien Penyakit Ginjal Kronik (PGK). Ketidakseimbangan zat gizi pada pasien PGK ini, maka diperlukan suatu pengetahuan mengenai hal-hal yang dapat mempengaruhi status gizi pasien hemodialisis. Penelitian ini bertujuan untuk mengetahui faktor-faktor yang mempengaruhi status gizi pasien yang menjalani terapi hemodialisis. Penelitian ini merupakan penelitian analitik observasional dengan pendekatan cross sectional. Penelitian ini dilakukan pada pasien PGK yang menjalani hemodialisis di RS Stella Maris Makassar dengan jumlah sampel 66 subjek menggunakan teknik non probability sampling dengan pendekatan consecutive sampling. Pengumpulan data untuk variabel nafsu makan menggunakan kuesioner Simplified Nutrirional Appetite Questionnaire (SNAQ), lama hemodialisis menggunakan lembar pengumpulan data karakteristik dan status gizi menggunakan indeks massa tubuh (IMT). Uji statistik yang digunakan adalah Uji Chi Square dan Uji Kolmogorov Smirnov untuk mengetahui hubungan antar variabel. Hasil analisis uji statistik menunjukkan bahwa ada hubungan antara nafsu makan dengan status gizi ( $p$ value $=0.000$ ) dan tidak ada hubungan antara lama hemodialisis dengan statu gizi ( $p$ value=1,000). Hasil penelitian ini didapatkan bahwa tidak ada hubungan antara lama hemodialisis dengan status gizi pasien hemodialisa di Rumah Sakit Stella Maris Makassar dan ada hubungan antara nafsu makan dengan status gizi pasien hemodialisa di Rumah Sakit Stella Maris Makassar. Oleh sebab itu, perlu adanya pemantauan secara berkala oleh petugas kesehatan mengenai nafsu makan pada pasien hemodialisis untuk mencegah terjadinya malnutrisi pada pasien.
\end{abstract}

\section{Corresponding Author:}

Yunita Carolina Satti,

Prodi Ilmu Keperawatan, STIK Stella Maris,

Jl. Maipa No. 19, Makassar, Indonesia.

Email: oline.yunita@gmail.com

\section{PENDAHULUAN}

Menurut World Health Organization (WHO) (2016), menyebutkan bahwa kasus penyakit ginjal kronik di dunia secara global lebih dari 10-50 juta orang. Prevalensi penyakit ginjal kronik di Indonesia sekitar 3,8\% dan prevalensi penyakit ginjal kronik untuk provinsi Sulawesi Selatan sebesar 3,4\% (Riskesdas, 2018). Berdasarkan data Report Of Indonesian Renal Registry (2016), menunjukkan proporsi diagnosa utama pasien yang menjalani hemodialisa adalah penyakit ginjal kronik dengan prevalensi sebesar 22.170 orang (90\%) sedangkan prevalensi penyakit ginjal kronik di dunia yang harus menjalani hidup dengan bergantung pada terapi hemodialisa sebanyak 1,5 juta orang.

Penyakit Ginjal Kronik (PGK) merupakan kegagalan fungsi ginjal untuk mempertahankan metabolisme serta keseimbangan cairan dan elektrolit akibat destruksi struktur ginjal yang progresif dengan manifestasi penumpukan sisa metabolit (toksin uremik) di dalam darah (Muttaqin \& Sari, 2014). Penyakit ginjal kronik merupakan masalah kesehatan masyarakat global dengan prevalens dan insidens gagal ginjal yang meningkat, prognosis yang buruk dan biaya yang tinggi (Kemenkes, 2017). 
Menurut data Report Of Indonesian Renal Registry (2017) jumlah pasien baru yang menjalani hemodialisis terus meningkat dari tahun ke tahun, pasien baru yang menjalani terapi hemodialisa sebanyak 30.831 orang dan yang masih aktif menjalani terapi hemodialisa sebanyak 77.892 orang dan sebagian besar pasien menghentikan terapi hemodialisa karena meninggal dunia sebesar 4.021 orang (70\%). Menurut data Report Of Indonesian Renal Registry (2016) di Sulawesi Selatan jumlah tindakan hemodialisa sebanyak 9.312 orang. Sedangkan berdasarkan data Medical Record Rumah Sakit Stella Maris Makassar jumlah pasien gagal ginjal pada tahun 2018 sebanyak 456 orang dan jumlah pasien gagal ginjal pada tahun 2019 sampai bulan September sebanyak 365 orang. Jumlah tindakan yang dilakukan di ruang hemodialisis pada tahun 2018 sebanyak10.443 kali sedangkan pada tahun 2019 sampai bulan September sebanyak 6.899 kali.

Penyakit ginjal kronik dapat berkembang secara perlahan ke arah yang semakin buruk di mana ginjal tidak mampu lagi bekerja sebagaimana fungsinya sehingga dapat memicu munculnya komplikasi. Beberapa komplikasi yang sering muncul akibat PGK adalah penyakit jantung, gangguan tulang dan mineral, anemia serta malnutrisi (Ariani, 2016). Pada pasien PGK gejala pertama dan utama yang muncul adalah malnutrisi yang disebabkan oleh proses uremik yang memberikan gejala utama anoreksia dan mual. Walaupun pasien telah menjalani hemodialisis dengan diet yang dibatasi, malnutrisi masih merupakan masalah utama pada pasien PGK sehingga dapat mengakibatkan status gizi buruk pada pasien (Puspawati, 2017). Semakin jelek status nutrisi penderita PGK maka semakin jelek juga kualitas hidupnya (Sagala, 2015). Bagi penderita PGK, hemodialisis (HD) merupakan terapi pengganti ginjal yang banyak dipilih tetapi tidak menghilangkan penyakitnya (Siagian, 2018). Namun, hemodialisis berdampak pada status gizi pasien, oleh karena prosedur dialisis mengakibatkan hilangnya nutrisi ke dalam dialisat dan meningkatkan proses katabolisme, sehingga dapat menyebabkan malnutrisi (Salawati, 2016).

Berdasarkan hasil wawancara singkat yang peneliti lakukan pada pasien yang menjalani HD di Rumah Sakit Stella Maris Makassar didapatkan ada beberapa pasien yang memiliki IMT kurang. Penurunan Berat Badan pada pasien HD dipicu akibat rasa mual dan muntah yang di alami pasien sehingga dapat mempengaruhi status gizi pasien. Pasien juga mengatakan selama menjalani HD berat badan pasien kadang naik dan kadang juga turun bahkan mengalami penurunan sampai $10 \mathrm{~kg}$ dan perubahan yang terjadi pada status gizi pasien tersebut bukan karena edema.

Penurunan nafsu makan pada pasien PGK penyebabnya multi faktor, salah satunya adalah sindrom uremia dimana pasien akan merasa mual, muntah dan hilangnya cita rasa. Hal ini akan menyebabkan malnutrisi energi protein yang akan mempermudah terjadinya inflamasi kronik dan komorbid (Sari, Sugiarto, Probandari, \& Hanim, 2017). Pasien PGK dengan penurunan nafsu makan memiliki resiko kematian dua kali lebih besar $(\mathrm{RR}=2,23)$ dibandingkan dengan pasien dengan nafsu makan baik (Rokhmah et al., 2017). Sementara proses difusi pada prosedur dialisis juga akan mengakibatkan hilangngnya nutrisi pasien sehingga semakin lama pasien menjalani hemodialisis maka nutrisi pasien akan semakin berkurang dan pada akhirnya menyebabkan berbagai gangguan metabolik, penurunan fungsi jaringan dan hilangnya massa tubuh (Salawati, 2016).

Menurut Insani, Ayu, \& Anggraini (2019) kasus malnutrisi ditemukan di awal hemodialisis pada penderita PGK sebanyak 40\%. Penurunan berat badan pada penderita PGK mulai terlihat setelah 3 bulan menjalani hemodialisis dan penurunan berat badan secara signifikan setelah 1 tahun menjalani hemodialisis. Status gizi yang buruk akan menyebabkan malaise dan fatigue, rehabilitasi jelek, penyembuhan luka terganggu, kepekaan terhadap infeksi meningkat, angka rawat inap menigkat, morbiditas dan mortalitas juga meningkat maka dari itu diperlukan penatalaksanaan status gizi yang sangat penting pada pasien pra-dialisis untuk mencegah timbunan nitrogen, mempertahankan status gizi yang optimal untuk mencegah terjadinya malnutrisi, menghambat progresifitas kemunduran faal ginjal serta mengurangi gejala uremi dan gangguan metabolisme (Salawati, 2016). Banyak faktor yang mempengaruhi status gizi pada pasien HD diantaranya adalah penurunan nafsu makan dan lama hemodialisis. Berdasarkan uraian di atas, peneliti tertarik melakukan penelitian tentang faktor-faktor apa saja yang mempengaruhi status gizi pasien hemodialisa di Rumah Sakit Stella Maris Makassar. Tujuan dari penelitian ini adalah untuk mengetahui faktor-faktor yang berhubungan dengan status gizi pasien hemodialisis di Rumah Sakit Stella Maris Makassar.

\section{METODE PENELITIAN}

Penelitian ini merupakan jenis penelitian non-eksperimental yang tergolong dalam jenis penelitian observasional analitik dengan menggunakan pendekatan cross-sectional. Penelitian ini dilaksanakan di ruang Hemodialisis Rumah Sakit Stella Maris Makassar. Penelitian dilaksanakan pada bulan Januari sampai bulan Februari 2020.

Populasi dalam penelitian ini berjumlah 80 orang. Pada penelitian ini sampel yang di ambil oleh peneliti adalah semua pasien yang menjalani terapi hemodialisis di ruang HD dengan menggunakan teknik non probability sampling dengan menggunakan pendekatan consecutive sampling, dengan kriteria inklusi responden adalah pasien yang bersedia menjadi responden dalam penelitian, pasien yang memahami bahasa 
Indonesia, pasien yang bisa membaca dan menulis. Sedangkan kriteria eksklusi adalah pasien yang mengalami penurunan kesadaran.

Nafsu makan pada pasien hemodialisis diukur menggunakan kuesioner yang di adaptasi dari Simplified Nutrirional Appetite Questionnaire (SNAQ) dan sudah diterjemahkan ke dalam Bahasa Indonesia. Kuesioner ini terdiri atas 4 item pertanyaan dan setiap jawaban akan diberi skor 1-5. Pertanyaan diisi dengan memilih jawaban nomor 1-5 dan melingkari salah satu jawaban yang menurut responden adalah jawaban yang tepat. Skor yang diberikan tentang nafsu makan yaitu Nafsu Makan Baik (jika skor 13-20) dan Nafsu Makan Kurang (jika skor 4-12). Lama HD diukur dengan menggunakan lembar kuesioner berupa lembar pengumpulan data karakteristik yang diperoleh dari responden, terbagi atas 2 kategori yaitu $\leq 5$ tahun dan $>5$ tahun. Status gizi dinilai dengan mengukur TB dan BB kering pasien untuk memperoleh nilai IMT. TB di ukur pada saat pasien datang ke Ruang Hemodialisa untuk menjalani terapi hemodialsisi dan Berat badan kering di ukur setelah post dialisis, yang merupakan berat badan paling rendah yang dicapai pasien tanpa disertai keluhan dan gejala hipotensi. Setelah data terkumpul peneliti melakukan perhitungan terhadap status gizi pasien dengan menggunakan rumus IMT = berat badan $(\mathrm{kg}) /$ tinggi badan $\left(\mathrm{m}^{2}\right)$ dengan kategori Lebih (jika IMT $\geq 25,00$ ), Normal (jika IMT 18,5-24,99) dan Kurang (jika IMT < 18,5).

\section{HASIL}

\subsection{Karakteristik Responden}

Tabel 1. Karakteristik Responden

\begin{tabular}{|c|c|c|}
\hline & Frekuensi (f) & Persentase $(\%)$ \\
\hline \multicolumn{3}{|l|}{ Jenis Kelamin } \\
\hline Laki-Laki & 40 & 60.6 \\
\hline Perempuan & 26 & 39.4 \\
\hline Total & 66 & 100 \\
\hline \multicolumn{3}{|l|}{ Umur } \\
\hline $26-35$ thn & 7 & 10.6 \\
\hline $36-45$ thn & 12 & 18.2 \\
\hline $46-55$ thn & 15 & 22.7 \\
\hline $56-65$ thn & 21 & 31.8 \\
\hline 66 thn-atas & 11 & 16.7 \\
\hline Total & 66 & 100.0 \\
\hline \multicolumn{3}{|l|}{ Nafsu Makan } \\
\hline $\begin{array}{c}\text { Nafsu Makan } \\
\text { Baik }\end{array}$ & 40 & 60.6 \\
\hline Nafsu Makan & 26 & 39.4 \\
\hline Kurang & & \\
\hline Total & 66 & 100 \\
\hline \multicolumn{3}{|l|}{ Lama Hemodialisis } \\
\hline$\leq 5$ thn & 56 & 84.8 \\
\hline$>5$ thn & 10 & 15.2 \\
\hline Total & 66 & 100 \\
\hline \multicolumn{3}{|l|}{ Status Gizi } \\
\hline Lebih & 10 & 15.2 \\
\hline Normal & 33 & 50.0 \\
\hline Kurang & 23 & 34.8 \\
\hline Total & 66 & 100 \\
\hline
\end{tabular}


Berdasarkan tabel 1. Diatas dapat diketahui bahwa pasien yang menjalani hemodialisis di Rumah Sakit Stella Maris Makassar, mayoritas responden berjenis kelamin laki-laki yaitu sebanyak 40 responden $(60.6 \%)$ dan mayoritas responden berada pada kisaran umur 56-65 thn dengan frekuensi 21 responden $(31,8 \%)$. Sedangkan responden dengan kategori nafsu makan baik yaitu sebanyak 40 responden $(60.6 \%)$ dan responden dengan kategori lama hemodialisis $\leq 5$ thn sebanyak 56 responden $(84.8 \%)$ dan responden yang menjalani hemodialisa di Rumah Sakit Stella Maris Makassar yang memiliki status gizi terbanyak yaitu pada kategori normal sebanyak $33(50.0 \%)$ responden.

\subsection{Analisis Bivariat}

Tabel 2. Analisis Hubungan Nafsu Makan Dengan Status Gizi Pasien Hemodialisa

\begin{tabular}{|c|c|c|c|c|c|c|c|c|c|}
\hline \multirow{3}{*}{ Nafsu Makan } & \multicolumn{6}{|c|}{ Status Gizi } & \multirow{2}{*}{\multicolumn{2}{|c|}{ Total }} & \multirow{3}{*}{$p$} \\
\hline & \multicolumn{2}{|c|}{ Lebih } & \multicolumn{2}{|c|}{ Normal } & \multicolumn{2}{|c|}{ Kurang } & & & \\
\hline & $\mathrm{f}$ & $\%$ & $f$ & $\%$ & $f$ & $\%$ & $\mathrm{n}$ & $\%$ & \\
\hline $\begin{array}{c}\text { Nafsu Makan } \\
\text { Baik }\end{array}$ & 9 & 13.6 & 26 & 39.4 & 5 & 7.6 & 40 & 60.6 & \\
\hline $\begin{array}{c}\text { Nafsu Makan } \\
\text { Kurang }\end{array}$ & 1 & 1.5 & 7 & 10.6 & 18 & 27.3 & 26 & 39.4 & \\
\hline Total & 10 & 15.2 & 33 & 50.0 & 23 & 34.8 & 66 & 100 & \\
\hline
\end{tabular}

Berdasarkan tabel 2 diatas dapat diketahui bahwa berdasarkan hasil uji statistik menggunakan uji Chi-Square tabel $2 \times 3$ dengan nilai kemaknaan $\alpha=0.05$ diperoleh $p$ value $=0.000$ yang dibaca pada Pearson Chi Square dengan nilai expected count $<5$, tidak lebih dari $20 \%$ cell yang artinya memenuhi syarat uji $C h i$ Square. Hal ini menunjukkan bahwa nilai $p(0.000)<\alpha(0.05)$, maka hipotesis nol (Ho) ditolak dan hipotesis alternatif (Ha) diterima. Dengan demikian ada hubungan yang bermakna antara nafsu makan dengan status gizi pasien hemodialisa di Rumah Sakit Stella Maris Makassar.

Tabel 3. Analisis Hubungan Lama Hemodialisis Dengan Status Gizi Pasien Hemodialisa

\begin{tabular}{|c|c|c|c|c|c|c|c|c|c|}
\hline \multirow{3}{*}{$\begin{array}{c}\text { Lama } \\
\text { Hemodialisis }\end{array}$} & \multicolumn{6}{|c|}{ Status Gizi } & \multirow{2}{*}{\multicolumn{2}{|c|}{ Total }} & \multirow{3}{*}{$p$} \\
\hline & \multicolumn{2}{|c|}{ Lebih } & \multicolumn{2}{|c|}{ Normal } & \multicolumn{2}{|c|}{ Kurang } & & & \\
\hline & $\mathrm{f}$ & $\%$ & $f$ & $\%$ & $f$ & $\%$ & $\mathrm{n}$ & $\%$ & \\
\hline$\leq 5$ thn & 8 & 12.1 & 28 & 42.4 & 20 & 30.3 & 56 & 84.8 & \multirow{3}{*}{1,000} \\
\hline$>5$ thn & 2 & 3,0 & 5 & 7,6 & 3 & 4.5 & 10 & 15.2 & \\
\hline Total & 10 & 15.2 & 33 & 50.0 & 23 & 34.8 & 66 & 100 & \\
\hline
\end{tabular}

Berdasarkan tabel 3 diatas dapat diketahui bahwa berdasarkan hasil uji statistik menggunakan uji Chi-Square tabel $2 \times 3$ dengan nilai kemaknaan $\alpha=0.05$ dibaca pada Pearson Chi Square. Namun hasil uji statistik tersebut tidak bisa dibaca pada Pearson Chi Square karena nilai expected count $<5$, lebih dari $20 \%$ cell, sehingga langkah selanjutnya dilakukan uji alternatif Kolmogorov-Smirnov dan diperoleh nilai $p=$ 1,000. Hal ini menunjukkan bahwa nilai $p(1,000)>\alpha(0.05)$, maka hipotesis nol (Ho) diterima dan hipotesis alternatif (Ha) ditolak. Dengan demikian tidak ada hubungan lama hemodialisis dengan status gizi pasien hemodialisa di Rumah Sakit Stella Maris Makassar.

\section{DISKUSI}

\subsection{Analisis Karakteristik Responden Berdasarkan Usia dan Jenis Kelamin}

Semakin bertambahnya usia, sel-sel tubuh akan semakin melemah, termasuk fungsi organ tubuh yaitu ginjal akan menurun, hal itu merupakan hal yang fisiologis (Martonon \& Satino, 2014). Setelah usia > 30 tahun, ginjal akan mengalami atrofi dan ketebalan korteks ginjal akan berkurang sekitar 20\% setiap 10 tahun dan jumlah nefron yang berfungsi berkurang 10\% setiap 10 tahun. Perubahan lain yang akan terjadi yaitu penebalan membran basal glomerulus, ekspansi mesangium glomerular dan terjadinya deposit protein 
matriks ekstraselular sehingga menyebabkan glomerulosklerosis (Arifa, Azam, \& Handayani, 2017). Jika terjadi penurunan fungsi ginjal akan mengakibatkan ginjal kehilangan beberapa nefron sehingga terjadi penurunan laju filtrat glomerulus. Penurunan laju filtrasi glomerulus (akibat tidak berfungsinya glomeruli) berdampak pada klirens kreatinin akan menurun dan kadar kreatinin serum akan meningkat. Kemudian akan berlanjut dengan kegagalan ginjal secara progresif. Penurunan massa otot yang terjadi pada individu yang lebih tua juga menyebabkan penurunan kecepatan pada produksi kreatinin karena itu didapatkan konsentrasi kreatinin serum normal meskipun bersihan serum kreatinin terganggu (Martonon \& Satino, 2014).

Berdasarkan hasil penelitian penderita Penyakit Ginjal Kronik yang menjalani HD di RS Stella Maris Makassar didapatkan kelompok usia terbanyak adalah 56-65 thn sebanyak (31,8\%). Menurut asumsi peneliti umur berpengaruh terhadap terjadinya Penyakit Ginjal Kronik karena terjadi penurunan fungsi fisiologis tubuh yaitu ginjal oleh karena proses penuaan. Hal ini didukung oleh penelitian yang dilakukan oleh Aisara, Azmi, \& Yanni (2018) yang mengatakan bahwa dengan bertambahnya usia seseorang maka risiko untuk mengalami PGK semakin meningkat, hal ini terjadi karena Glomerular Filtrasion Rate (GFR) dan Renal Blood Flow (RBF) dapat mengalami penurunan yang progresif, dimana penurunan tersebut terjadi sekitar $8 \mathrm{ml} / \mathrm{menit} / 1,73 \mathrm{~m}^{2}$ setiap dekadenya (10 tahun) sejak usia 40 tahun.

Menurut Martonon \& Satino (2014) laki-laki sangat berisiko mengalami gangguan fungsi ginjal, hal ini disebabkan struktur dan anatomi saluran perkemihan yang panjang dan juga aliran urin yang lama, sehingga beresiko menempelnya sampah atau sisa metabolisme pada saluran kemih. Kondisi tersebut memicu terjadinya obstruksi pada saluran kemih sehingga terjadi refluks dan resiko infeksi pada ginjal. Anatomi saluran kemih laki-laki jauh lebih panjang dari pada perempuan. Hal ini memungkinkan resiko terjadinya pengendapan zat-zat yang terkandung dalam urin lebih banyak dibanding perempuan. Pengendapan dengan proses yang lama dapat membentuk batu baik pada saluran kemih maupun pada ginjal. Bila gangguan fungsi ginjal ini berlangsung secara progresif dapat menimbulkan gagal ginjal pada tahap terminal. Bila ditinjau dari jenis kelamin dan status fisiologi, laki-laki mempunyai blood ureum nitrogen ratarata sedikit lebih tinggi dari wanita karena tubuh pria memiliki lean body mass yang lebih besar. Nilai laju filtrasi glomerulus rate laki-laki juga lebih tinggi dari pada perempuan oleh karena massa ginjal laki-laki relatif lebih besar dari pada perempuan.

Dalam penelitian ini mayoritas responden berjenis kelamin laki-laki yaitu sebanyak 40 orang. Hal ini sesuai dengan penelitian yang dilakukan oleh Insani et al., (2019) bahwa frekuensi pasien PGK yang menjalani hemodialisis lebih banyak pada laki-laki yaitu $(55,4 \%)$ dibandingkan perempuan (44,6\%). Menurut Arifa et al., (2017) responden yang berjenis kelamin laki-laki berisiko 1,783 kali lebih besar terkena PGK dibandingkan dengan responden yang berjenis kelamin perempuan. Dan sesuai juga dengan penelitian Aisara et al., (2018) yang dilakukan di RSUP Dr. M. Djamil Padang, sebagian besar responden diketahui berjenis kelamin laki-laki $(56,7 \%)$ dan sisanya diketahui berjenis kelamin perempuan $(43,3 \%)$.

Secara klinis laki-laki mempunyai risiko mengalami penyakit ginjal kronik 2 kali lebih besar dari pada perempuan. Hal ini dimungkinkan karena laki-laki lebih banyak mempunyai kebiasaan yang dapat mempengaruhi kesehatan seperti merokok, minum kopi, alkohol dan minuman suplemen yang dapat memicu terjadinya penyakit sistemik yang dapat menyebabkan penurunan fungsi ginjal (Arifa et al., 2017).

\subsection{Hubungan Nafsu Makan Dengan Status Gizi Pasien Hemodialisis}

Berdasarkan hasil penelitian diketahui bahwa terdapat hubungan antara nafsu makan dan status gizi pada pasien yang menjalani hemodialisis. Hasil uji statistik dengan menggunakan uji Chi Square, diperoleh nilai $p=0,000$, hal ini menunjukkan nilai $p<\alpha(0,05)$, maka hipotesis nol (Ho) ditolak dan hipotesis alternatif (Ha) diterima artinya ada hubungan yang bermakna antara nafsu makan dengan status gizi pasien hemodialisis di Rumah Sakit Stella Maris Makassar. Nutrisi merupakan faktor penting bagi pasien yang menjalani hemodialisis mengingat adanya efek uremia yaitu mual dan muntah yang berdampak pada penurunan nafsu makan. Apabila ginjal yang rusak tidak mampu mengekresikan produk akhir metabolisme, substansi yang bersifat asam ini akan menumpuk dalam serum pasien dan bekerja sebagai racun atau toksin. (Santoso et al., 2016).

Akibat tingginya kadar ureum dan kreatinin di dalam darah pasien yang menjalani HD, dapat merangsang produksi asam lambung, sehingga menyebabkan keluhan mual, muntah, perih ulu hati dan kembung. Jika hal ini dirasakan oleh pasien akan mengakibatkan pasien malas untuk makan dan akan menimbulkan perasaan yang tidak nyaman pada perut pasien sehingga akan menyebabkan pasien menolak untuk makan atau tidak mampu menghabiskan sejumlah makanan yang disajikan. Masalah gastrointestinal seperti mual dan muntah merupakan hal yang wajar dirasakan bagi pasien yang menjalani hemodialisis. Hal ini sejalan dengan hasil survey kuesioner yang didapatkan yaitu sebanyak 24.2\% responden mengatakan rasa makanan yang biasa dimakan tidak enak, dimana jika pasien mengeluhkan rasa makanan yang dimakan tidak enak akan membuat pasien malas untuk makan. Gangguan gastrointestinal pada pasien penyakit ginjal kronik 
juga disebabkan oleh perlambatan pengosongan dan gangguan aktifitas mioelektrik pada lambung (Rokhmah et al., 2017). Maka semakin kurang nafsu makan pasien maka status gizinya akan semakin menurun.

Mekanisme penyebab terjadinya kehilangan keinginan untuk makan pada pasien yang menjalani hemodialisis pada dasarnya tidak diketahui secara pasti, namun pengaruh racun uremia, inflamasi, kadar hormon leptin, ghrelin dan neuropeptide $Y$ dianggap dapat mempengaruhi nafsu makan pada pasien yang menjalani hemodialisis (Khairunnisa, 2012). Nafsu makan dapat mengontrol asupan makan. Pengaturan asupan makanan tidak hanya dipengaruhi oleh satu sinyal, tetapi juga ditentukan oleh integrasi berbagai input termasuk efek dari hormon (Djafar dan Sulistyowati, 2016).

Hal ini sejalan dengan penelitian Siagian (2018) yang menyatakan bahwa beberapa pasien yang menjalani hemodialisis mengalami penurunan nafsu makan sehingga frekuensi makannya tidak teratur. Selain itu kendala yang dihadapi responden dalam pemenuhan nutrisi antara lain gangguan pencernaaan dan perubahan selera makan. Salah satu faktor gizi kurang yaitu nafsu makan kurang, berimplikasi pada rendahnya konsumsi makanan dimana pasien justru membutuhkan asupan energi terutama protein yang cukup untuk mengatasi kekurangan zat gizi akibat proses hemodialisa. Dengan penggunaan hemodialisa yang efektif, asupan makanan pasien dapat diperbaiki meskipun biasanya memerlukan beberapa penyesuaian atau pembatasan pada asupan protein, natrium, kalium dan cairan. Jika status gizi pasien baik maka nafsu makannya juga baik (Santoso et al., 2016). Maka dari itu dibutuhkan pencegahan yang tepat untuk mengompensasi nutrisi yang ikut terbuang tiap sesi hemodialisis, terutama protein yang mencapai 10-12 gram tiap sesinya. NKF-K/DOQI (2000) merekomendasikan asupan protein untuk pasien PGK yang menjalani hemodialisisis adalah $1,2 \mathrm{gram} / \mathrm{kgBB} / \mathrm{hari}$. Asupan protein yang dianjurkan adalah asupan protein dengan nilai biologis tinggi (protein hewani). Jika pasien tidak mengikuti rekomendasi ini maka akan mengakibatkan pasien dapat mengalami penurunan berat badan, akibat pasien tidak melaksanakan diet yang sudah direkomendasikan (Dewantari et al., 2014).

Berdasarkan hasil wawancara yang dilakukan oleh peneliti ada beberapa responden mengatakan masih kurang mendapatkan konseling mengenai diet yang harus dijalankan. Mereka mengatakan tidak mengetahui makanan apa saja yang mengandung protein, sehingga mereka tidak menjalankan diet yang sudah direkomendasikan yaitu memakan makanan yang mengandung protein. Apabila konsumsi makanan pasien yang mengandung protein kurang maka dapat mempengaruhi status nutrisi pasien. Selain itu responden juga mengatakan kadang susah untuk mengikuti aturan diet karena merasa bosan dengan makanan yang lauknya sama setiap hari. Maka peneliti menyarankan agar pasien bertanya kepada petugas kesehatan jika ada hal yang kurang dipahami atau menayakan mengenai anjuran diet untuk pasien HD, selain itu pasien juga dapat mencari anjuran mengenai diet pasien HD di internet untuk menambah wawasan mereka. Seperti halnya yang dilakukan oleh pasien lain yang memiliki nafsu makan baik dengan status gizi normal agar tidak ada lagi pasien HD yang memiliki nafsu makan baik namun status gizinya kurang akibat proses hemodialisis. Selain itu peran keluarga dalam memberikan dukungan kepada pasien dalam menjalankan diet sangat diperlukan. Jika pasien mulai bosan dengan makan yang sama setiap hari, keluarga dapat meminta saran dari petugas kesehatan dalam memberikan variasi makanan, tetapi tetap menjalankan diet.

Sebagai pemberi asuhan keperawatan seorang perawat hemodialisis dituntut untuk mengetahui kondisi pasiennya terutama tentang kebutuhan diet yang harus dijalani, agar dapat memenuhi kebutuhan kesehatan secara holistik dan mencapai tujuan yang diinginkan oleh klien. Hendaknya perawat hemodialisis juga mampu untuk berkolaborasi dengan tim kesehatan lain terutama tim gizi untuk mencapai tujuan yang sama dalam mencapai kesehatan pasien yang optimal, serta mampu mengambil keputusan bersama dalam memecahkan masalah. Sehingga perawat tidak hanya mampu melaksanakan pelayanan kesehatan semata, tetapi juga mampu menganalisis proses standart pencapaian gizi pada pasien (Kuswati, 2014).

\subsection{Hubungan Lama Hemodialisis Dengan Status Gizi Pasien Hemodialisis}

Berdasarkan hasil penelitian menunjukkan bahwa tidak terdapat hubungan antara lama hemodialisis dengan status gizi pasien hemodialisis berdasarkan IMT. Hal ini dapat dilihat dari hasil uji chi square nilai $\mathrm{p}$ value sebesar 1,000 ( $p>0,05)$. Dari hasil tersebut dapat disimpulkan bahwa hipotesis nol (Ho) diterima dan hipotesis alternatif (Ha) ditolak, yang berarti tidak ada hubungan secara signifikan antara lama hemodialisis dengan status gizi pasien hemodialisa di RS Stella Maris makassar.

Menurut Salawati (2016) penderita PGK yang menjalani hemodialisis $>1$ tahun berisiko 1,99 kali dapat mengalami malnutrisi. Dalam penelitian tersebut menjelaskan proses difusi pada prosedur dialisis dilakukan dengan mengalirkan darah ke dalam suatu tabung ginjal buatan (dialiser) yang terdiri dari dua kompartemen terpisah. Besar pori pada selaput akan menentukan besar molekul zat terlarut yang berpindah. Molekul dengan berat molekul lebih besar akan berdifusi lebih lambat dibanding molekul dengan berat molekul lebih rendah. Proses ini dapat mengakibatkan hilangnya nutrisi pasien sehingga semakin lama pasien menjalani hemodialisis maka nutrisi pasien akan semakin berkurang dan pada akhirnya menyebabkan berbagai gangguan metabolik, penurunan fungsi jaringan dan hilangnya massa tubuh. 
Selain faktor di atas menurut Santoso et al., (2016) bagi pasien yang menjalani hemodialisis memerlukan pengobatan jangka panjang sehingga akan memberikan pengaruh-pengaruh bagi penderita seperti tekanan psikologi bagi penderita. Pasien yang telah lama menjalani terapi hemodialisis cenderung memiliki tingkat cemas lebih rendah dibandingkan dengan responden yang baru menjalani hemodialisis, hal ini disebabkan karena dengan lamanya seseorang menjalani hemodialisis, maka seseorang akan lebih adaptif dengan tindakan dialisis. Pasien yang sudah lama menjalani terapi hemodialisis kemungkinan sudah dalam fase penerimaan. Pertama kali pasien penyakit ginal kronik didiagnosa harus menjalani dialisis jangka panjang. Pengobatan yang lama merupakan beban dilihat dari segi biaya yang harus dikeluarkan, suntikansuntikan yang sekian lama harus diterima, dirasakan cukup membosankan. Namun lama menjalani hemodialisis bukanlah sebuah jaminan bahwa pasien tidak akan merasakan cemas karena baik pada pasien yang baru dan yang sudah lama menjalani hemodialisis bisa saja sewaktu-waktu mengalami kecemasan. Efek kecemasan yang dialami pasien, akan menimbulkan perasaan mual ringan sehingga memberikan perasaan kenyang di perut. Selanjutnya perasaan penuh di tenggorokan dan kesulitan menelan juga dapat menekan keinginan untuk makan. Adanya ketakutan dan pikiran-pikiran negatif pun terkadang berimplikasi pada berkurangnya nafsu makan dan penolakan makan (Khairunnisa, 2012).

Menurut Isroin (2017) tingkat adaptasi pasien yang menjalani hemodialisis sebagai sistem adaptasi dipengaruhi oleh perkembangan pasien itu sendiri, dan penggunaan mekanisme koping. Pasien yang baru menjalani hemodialisis masih mencoba beradaptasi dengan kondisi yang ada, semakin lama pasien menjalani hemodialisis maka pasien semakin patuh untuk melakukan hemodialisis karena pasien sudah dapat menerima keadaannya dan juga telah diberitahukan tentang penyakitnya dan pentingnya melaksanakan hemodialisis secara teratur oleh dokter atau perawat. Namun apabila pasien tidak mengikuti aturan yang diberikan seperti menjalankan diet yang diberikan dan mengikuti jadwal hemodialisis sesuai dengan yang telah direkomendasikan dapat mengakibatkan pasien mengalami ketidakmampuan untuk beradaptasi terhadap nutrisinya yang ditandai dengan adanya keluhan mual, muntah, tidak nafsu makan dan lemas. Biasanya responden yang mengalami keluhan atau maladaptif terhadap nutrisi hemodialisis kemungkinan pasien tersebut tidak patuh terhadap diit hemodilisis. Jadi kemampuan beradapatasi pasien tergantung dari pasien itu sendiri. Baik pasien yang baru atau yang sudah lama menjalani hemodialisis dapat mengalami status gizi yang kurang sebagai akibat pasien tidak mematuhi aturan yang sudah diberikan (Insani et al., 2019).

Belum banyak penelitian yang menghubungkan antara lama hemodialisis dengan status gizi. Namun, menurut asumsi peneliti temuan yang didapatkan oleh peneliti tidak sesuai dengan teori yang ada yaitu semakin lama menjalani hemodialisis akan mengakibatkan status gizi semakin berkurang oleh karena prosedur HD dapat mengakibatkan terjadi pembuangan zat-zat gizi yang masih di perlukan oleh tubuh atau tidak terdapatnya hubungan antara lama hemodialisis dengan status gizi dikarenakan baik pada pasien yang baru atau sudah lama menjalani hemodialisis, ada kemungkinan untuk memiliki kemampuan adaptasi yang kurang dengan penyakitnya. Adaptasi ini bisa dalam bentuk penerimaan terhadap penyakit, kepatuhan dalam menjalankan diet, dan kemampuan pasien dalam menghadapi masalah yang mungkin dihadapi terkait penyakitnya.

Banyak hal yang dapat mempengaruhi status gizi pasien yang menjalani hemodialisis, namun lama hemodialisis tidak dapat digunakan sebagai acuan untuk menentukan status gizi pasien karena hal itu kembali lagi pada tingkat kemampuan adaptasi pasien HD. Selain kemampuan beradaptasi pasien terdapat banyak faktor yang dapat menyebabkan malnutrisi pada pasien PGK, hal terpenting adalah asupan makan yang kurang, meningkatnya katabolisme, dan inflamasi kronik. Faktor lainnya adalah tidak adekuatnya prosedur hemodialisis yang dapat menimbulkan mual dan muntah pada pasien. BUN (ureum) merupakan salah satu unsur penting yang dapat mempengaruhi nafsu makan seorang pasien PGK, semakin tinggi nilai BUN maka gejala gastrointestinal akan semakin berat, seperti mual dan muntah. Hal ini dikarenakan kadar BUN yang tinggi akan menyebabkan terjadinya edema pada mukosa lambung dan peningkatan asam lambung pasien (Kuswati, 2014).

\section{KESIMPULAN}

Berdasarkan hasil penelitian dapat disimpulkan bahwa ada hubungan antara nafsu makan dengan status gizi pasien hemodialisa di Rumah Sakit Stella Maris Makassar dan tidak ada hubungan antara lama hemodialisis dengan status gizi pasien hemodialisa di Rumah Sakit Stella Maris Makassar. Saran bagi peneliti selanjutnya agar dapat meneliti factor-faktor lain yang dapat mempengaruhi status gizi pasien yang menjalani terapi hemodialisis dan perlu penelitian lebih lanjut menggunakan metode penilaian status gizi dengan survey konsumsi makan pasien PGK dan analisis komposisi tubuh sebagai pemeriksaan terbaik untuk melihat status gizi pasien PGK serta perhitungan kalori dan menggunakan metode penelitian kualitatif untuk lebih mendalami status gizi pasien HD. 


\section{REFERENSI}

Aisara, S., Azmi, S., \& Yanni, M. (2018). Gambaran Klinis Penderita Penyakit Ginjal Kronik yang Menjalani Hemodialisis di RSUP Dr. M. Djamil Padang. Jurnal Kesehatan Andalas, 7(1), 42. https://doi.org/10.25077/jka.v7.i1.p42-50.2018.

Ariani, S. (2016). Stop Gagal Ginjal dan Gangguan-Gangguan Ginjal Lainnya. Yogyakarta: Istana Media.

Arifa, S. I., Azam, M., \& Handayani, O. W. K. (2017). Faktor Yang Berhubungan Dengan Kejadian Penyakit Ginjal Kronik Pada Penderita Hipertensi Di Indonesia. Media Kesehatan Masyarakat Indonesia, 13(4), 319.

Dewantari, Taruna, Angraini, \& Dilangga. (2014). Hubungan Adekuasi Hemodialisis dengan Asupan Makan dan Indeks Massa Tubuh Pasien Gagagal Ginjal Kronik yang Menjalani Hemodialisis di RSUD Abdul Moeloek Bandar Lampung. Jurnal Kedokteran Unila, 60-68.

Indonesia Renal Registry (IRR). (2017). Program Indonesian Renal Registry.

Indonesian Renal Registry (IRR). (2016). Program Indonesian Renal Registry. 1-46.

Insani, A. A., Ayu, P. R., \& Anggraini, D. I. (2019). Hubungan Lama Menjalani Hemodialisis Dengan Status Nutrisi Pada Pasien Penyakit Ginjal Kronik ( PGK ) Di Instalasi Hemodialisa RSUD Dr . H . Abdul Moeloek Provinsi Lampung. Jurnal Kedokteran Unila, 8, 55-59

Isroin, L. (2017). Adaptasi psikologis pasien yang menjalani hemodialisis. Jurnal EDUNursing, 1(1), 12-21.

Khairunnisa, A. (2012). Faktor-Faktor Yang Berhubungan Dengan Nafsu Makan Kurang Pada Pasien Hemodialisis Di RSPAD Gatot Soebroto. (Skripsi). Retrieved from http://lib.ui.ac.id/file?file=digital/20357809-SAnnisa\%20Khairunnisa.pdf. diakses pada tanggal 6 Oktober 2019.

Kuswati, W. (2014). Hubungan Adekuasi Hemodialisis Berdasarkan Parameter Urea Reduction Ratio ( URR ) Dengan Status Gizi : Malnutrition Inflammation Score (MIS ) Pada Pasien Yang Menjalani Hemodialisis Reguler di RSD dr. Soebandi Jember. Retrieved from http://digilib.unmuhjember.ac.id/files/disk1/50/umj-1x-worokuswat2472-1-jurnal.pdf. diakses pada tanggal 31 Oktober 2019.

Martonon, \& Satino. (2014). Deteksi keparahan fungsi ginjal melalui perubahan kritis laju filtrasi glomerulus pasien hemodialisa. Jurnal Ners, 9(1), 43-48.

Muttaqin, A., \& Sari, K. (2014). Asuhan Keperawatan Gangguan Sistem Perkemihan. Jakarta: Salemba Medika.

Puspawati, N. W. (2017). Penatalaksanaan Nutrisi Pada Penyakit Ginjal Kronik dengan Dialisis. 1-11.

Riskesdas. (2018). Hasil Utama Riskesdas Penyakit Tidak Menular 2018. Hasil Utama Riskesdas Penyakit Tidak Menular, 8.

Rokhmah, U. F., Purnamasari, D. U., \& Saryono. (2017). Faktor-Faktor yang Berhubungan dengan Penurunan Nafsu Makan pada Pasien Gagal Ginjal Kronik yang Menjalani Terapi Hemodialisis. 1. Retrieved from https://doi.org/10.20884/1.jgps.2017.1.01.343. diakses pada tanggal 25 September 2019.

Sagala, D. S. P. (2015). Analisa Faktor-Faktor yang Mempengaruhi Kualitas Hidup Pasien Gagal Ginjal Kronik yang Menjalani Hemodialisis di Rumah Sakit Umum Pusat Haji Adam Malik Medan. Jurnal Ilmiah Keperawatan IMELDA, 1(1), 8-16.

Salawati, L. (2016). Analisis Lama Hemodialisis dengan Status Gizi Penderita Penyakit Ginjal Kronik. 64-68. Retrieved from http://www.jurnal.unsyiah.ac.id/JKS/article/download/5298/4445. diakses pada tanggal 3 Oktober 2019.

Santoso, B. R., Manatean, Y., \& Asbullah. (2016). Hubungan Lama Hemodialisis dengan Penurunan Nafsu Makan pada Pasien Gagal Ginjal Kronik di Unit Hemodialisa RSUD Ulin Banjarmasin. 7(1), 41-45. Retrieved from https://doi.org/10.16861/j.cnki.zggc.2016.0213. diakses pada tanggal 14 Februari 2020

Sari, R., Sugiarto, Probandari, A., \& Hanim, D. (2017). Hubungan Asupan Energi, Protein, Vitamin B6, Natrium dan Kalium Terhadap Status Gizi Pada Pasien Gagal Ginjal Kronik dengan Hemodialisis. 6(2), 34-43. Retrieved from http://jab.stikba.ac.id/index.php/jab/article/viewFile/27/29. diakses pada tanggal 8 Oktober 2019.

Siagian, Y. (2018). Status Nutrisi Pasien Hemodialisa di Rumah Sakit Umum Daerah. Jurnal Keperawatan Silampari (JKS), 2(1), 300-3014. 